СИНТЕЗ ТА АНАЛІЗ БІОЛОГІЧНО АКТИВНИХ РЕЧОВИН

\author{
Recommended by Doctor of Chemistry, Professor M. Ye. Blazheyevskiy
}

UDC 66.094.941.094.7:543.068:547.292

https://doi.org/10.24959/nphj.18.2209

S. V. Kolisnyk, O. M. Svechnikova*, O. F. Vinnyk*, O. V. Kolisnyk, O. O. Altukhov

National University of Pharmacy

*Kharkiv National Pedagogical University named after G. S. Skovoroda

\title{
The reactivity of ethyl esters of 2-(benzoylamino) (1-R-2-oxoindoline-3-ylidene) acetic acids
}

The studies in a series of 2-(benzoylamino)(1-R-2-oxoindoline-3-ylidene) acetic acids and their derivatives have shown that compounds of the isostructural series exhibit the nootropic, antihypoxic, anabolic activity.

Aim. To study the reactivity of esters of 2-(benzoylamino)(1-R-2-oxoindoline-3-ylidene) acetic acids.

Materials and methods. The concentration of $\mathrm{NaOH}$ in the solution was determined by potentiometric titration on an EV-74 ionomer using the standard aqueous $\mathrm{HCl}$ solution. The reaction kinetics was performed in triplicates, the experiments contained 6-8 measurements (the depth of the change was not less than $80 \%$ ). The accuracy of the results obtained was assessed by the methods of mathematical statistics of small samples with statistical significance of 0.95 .

Results and discussion. The reaction rate constants of alkaline hydrolysis of esters of 2-(benzoylamino)(1-R-2oxoindoline-3-ylidene) acetic acids depend on the structure and the length of the hydrocarbon chain at the heterocyclic nitrogen atom. Introduction of hydrocarbon radicals to the structure of the heterocycle slows down the reaction, while the chain extension accelerates it. The effect of the electronic nature of the substituents on the reactivity of ethyl esters was quantitatively assessed by Hammett equation. The data obtained suggest that the values of the reaction parameter $\rho$ are positive in the temperature range studied; it is additionally confirmed by the $B_{A C} 2$ mechanism of this reaction.

Conclusions. The reaction kinetics of alkaline hydrolysis of biologically active ethyl esters of 2-(benzoylamino) (1-R-2-oxoindoline-3-ylidene) acetic acids has been studied in a wide temperature range; its $\mathrm{B}_{\mathrm{AC}} 2$ mechanism has been proven with formation of highly symmetrical intermediate. The effect of the substituents at the heterocyclic nitrogen atom on the numerous kinetic and activation parameters of the reaction has been analyzed; isokineticity and synchronicity of the reaction have been proven using independent tests. acids

Key words: reactivity; alkaline hydrolysis; derivatives of 2-(benzoylamino)(1-R-2-oxoindoline-3-ylidene) acetic

С. В. Колісник, О. М. Свєчнікова, О. Ф. Винник, О. В. Колісник, О. О. Алтухов

Реакційна здатність етилових естерів 2-(бензоїламіно)(1-R-оксоіндолін-3-іліден) оцтових кислот

Дослідження в ряду 2-(бензоїламіно)(1-R-2-оксоіндолін-3-іліден)оцтових кислот та їх похідних показали, що сполуки цих ізоструктурних рядів проявляють ноотропну, антигіпоксичну, анаболічну активність.

Мета роботи - дослідження реакційної здатності естерів 2-(бензоїламіно)(1-R-2-оксоіндолін-3-іліден)оцтових кислот.

Матеріали та методи. Концентрацію $\mathrm{NaOH}$ у розчині визначали потенціометричним титруванням на іономірі EV-74 стандартним водним розчином НCl. Кінетику реакції вивчали у трикратному повторенні, досліди містили 6-8 вимірів (глибина перетворень - не менше 80 \%). Оцінку точності одержаних результатів здійснювали методом математичної статистики малих вибірок при достовірній ймовірності 0,95.

Результати та їх обговорення. Константи швидкості реакції лужного гідролізу естерів 2-(бензоїламіно) (1-R-2-оксоіндолін-3-іліден)оцтових кислот залежать від структури та довжини вуглеводневого ланцюга при гетероциклічному атомі нітрогену. Введення до структури гетероциклу вуглеводневих радикалів уповільнює реакцію, а подовження ланцюга її прискорює. Кількісна оцінка впливу електронної природи замісників на реакційну здатність етилових естерів здійснювалась за рівнянням Гаммета. Одержані дані свідчать, що величини реакційного параметра р позитивні у вивченому температурному інтервалі, що додатково підтверджує $\mathrm{B}_{\mathrm{Ac}} 2$ механізм цієї реакції.

Висновки. Вивчена кінетика реакції лужного гідролізу біологічно активних етилових естерів 2-(бензоїламіно)(1-R-2-оксоіндолін-3-іліден)оцтових кислот у широкому температурному інтервалі, доведено її B 2 механізм з утворенням високосиметричного інтермедіату. Проаналізовано вплив природи замісників при гетероциклічному атомі Гідрогену на численні кінетичні та активаційні параметри реакції та доведена ізокінетичність та синхронність реакції з використанням незалежних тестів.

Ключові слова: реакційна здатність; лужний гідроліз; похідні 2-(бензоїламіно)(1-R-2-оксоіндолін-3іліден)оцтових кислот 


\section{С. В. Колесник, Е. Н. Свечникова, А. Ф. Винник, Е. В. Колесник, А. А. Алтухов}

\section{Реакционная способность этиловых эфиров 2-(бензоиламино)(1-R-оксоиндолин- 3-илиден)уксусных кислот}

Исследования в ряду 2-(бензоиламино)(1-R-2-оксоиндолин-3-илиден)уксусных кислот и их производных показали, что соединения этих изоструктурных рядов проявляют ноотропную, антигипоксическую, анаболическую активность.

Цель работы. Исследование реакционной способности эфиров 2-(бензоиламино)(1-R-2-оксоиндолин-3илиден)уксусных кислот.

Материалы и методы. Концентрацию $\mathrm{NaOH}$ в растворе определяли потенциометрическим титрованием на иономере EV-74 стандартным водным раствором HCl. Кинетику реакции изучали в трехкратной повторности, опыты содержали 6-8 определений (глубина преобразований - не менее 80 \%). Оценку точности полученных результатов проводили методом математической статистики малых выборок при достоверной вероятности 0,95.

Результаты и их обсуждение. Константы скорости реакции щелочного гидролиза эфиров 2-(бензоиламино) (1-R-2-оксоиндолин-3-илиден)уксусных кислот зависят от структуры и длины углеводородной цепи при гетероциклическом атоме азота. Введение в структуру гетероцикла углеводородных радикалов замедляет реакцию, а увеличение цепи ее ускоряет. Количественная оценка влияния электронной природы заместителей на реакционную способность этиловых эфиров проводилась по уравнению Гаммета. Полученные данные свидетельствуют, что величины реакционного параметра р позитивны в исследованном температурном интервале, что дополнительно подтверждает $\mathrm{B}_{\mathrm{AC}} 2$ механизм этой реакции.

Выводы. Изучена кинетика реакции щелочного гидролиза биологически активных этиловых эфиров 2-(бензоиламино)(1-R-2-оксоиндолин-3-илиден)уксусных кислот в широком температурном интервале, доказан еe $\mathrm{B}_{\mathrm{AC}} 2$ механизм с образованием высокосимметричного интермедиата. Проанализировано влияние природы заместителей при гетероциклическом атоме азота на многочисленные кинетические и активационные параметры реакции и доказана изокинетичность и синхронность реакции с использованием независимых тестов.

Ключевые слова: реакционная способность; щелочной гидролиз; производные 2-(бензоиламино)(1-R-2оксоиндолин-3-илиден)уксусных кислот

The studies in a series of 2-(benzoylamino)(1-R-2oxoindoline-3-ylidene) acetic acids and their derivatives have shown that compounds of these isostructural series exhibit the nootropic, antihypoxic, anabolic activity $[1,2]$.

It is known that esters of 2-(benzoylamino)(1-R-2oxoindoline-3-ylidene) acetic acids are the starting substances for the synthesis of the corresponding amides, hydrazides and their derivatives, and the reaction of their alkaline hydrolysis is one of the likely routes of metabolism in the body [3]. Therefore, the study of the reactivity of ethyl esters of 2-(benzoylamino)(1-R-2-oxoindoline-3-ylidene) acetic acids on the model reaction of their alkaline hydrolysis is of scientific and practical interest. In the literature there are no publications regarding the kinetics of alkaline hydrolysis of these compounds, therefore, it is advisable to study it. The aim of this work was to study the reactivity of esters of 2-(benzoylamino) (1-R-2-oxoindoline-3-ylidene) acetic acids; it will allow performing the QSAR-computer analysis for the targeted synthesis of new derivatives with diverse pharmacophore groups.

\section{Materials and methods}

Kinetic measurements were carried out according to the method [4]. The concentration of $\mathrm{NaOH}$ in the solution was determined by potentiometric titration on an EV-74 ionomer using the standard aqueous $\mathrm{HCl}$ solution. The reaction kinetics was performed in triplicates, the experiments contained 6-8 measurements (the depth of the change was not less than $80 \%$ ). The accuracy of the results obtained was assessed by the methods of mathematical statistics of small samples with statistical significance of 0.95 [4].
Ethyl ester of 2-(benzoylamino)(1-R-2-oxoindoline3-ylidene) acetic acids (1). Boil the solution of $2.9 \mathrm{~g}$ (0.01 Mol) 3-(5-oxo-2- phenyl-1,3-oxazole-4(5H)-ylidene)-1,3-dihydro- $2 \mathrm{H}$-indol-2-one in $50 \mathrm{~cm}^{3}$ of $96 \%$ ethanol on a water bath for 1 hour. In 2 hours filter the precipitate formed, wash with ethanol, dry and re-crystallize from ethanol. Compounds 2-6 are obtained similarly [5].

\section{Results and discussion}

The reaction kinetics was studied in the binary solvent of dioxane-water ( 60 vol. $\%$ of dioxane) in the temperature range of $45-85^{\circ} \mathrm{C}$. The reaction proceeds according to the equation given in Scheme 1.

The reaction obeys the kinetic equation of the second order:

$$
\frac{d x}{d t}=k \cdot(a-x) \cdot(b-x)
$$

where: $a, b-$ is the initial concentration of ester and alkali ( $\mathrm{mol} / \mathrm{L})$, respectively; $x$ - is the concentration of the reaction product $(\mathrm{mol} / \mathrm{L})$ at the time $\mathrm{t}(\mathrm{s}) ; k-$ is the bimolecular constant of the reaction rate $(\mathrm{L} / \mathrm{mol} \cdot \mathrm{s})$.

The distribution of variables and integration of equation (1) allow determining the rate constant for the reaction:

$$
k=\frac{2.303}{t \cdot(b-a)} \lg \frac{a \cdot(b-x)}{b \cdot(a-x)} .
$$

The value $k$ obtained was correlated to the increase of the amount of the solvent when the temperature of the experiment changed from $25{ }^{\circ} \mathrm{C}$ to ${ }^{\circ} \mathrm{C}$ by multiplying by the factor $T=d_{25} / d_{t}$ where $d_{25}$ and $d_{t}$ being the density of the dioxane-water binary solvent at $25^{\circ} \mathrm{C}$ and $t^{\circ} \mathrm{C}$. 


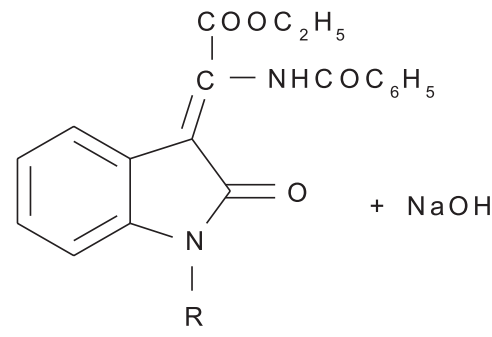

$\mathrm{R}=\mathrm{H}(1), \mathrm{CH} 3(2), \mathrm{C} 2 \mathrm{H} 5(3), \mathrm{n}-\mathrm{C} 3 \mathrm{H} 7(4), \mathrm{n}-\mathrm{C} 4 \mathrm{H} 9(5), \mathrm{C} 6 \mathrm{H} 5(6)$

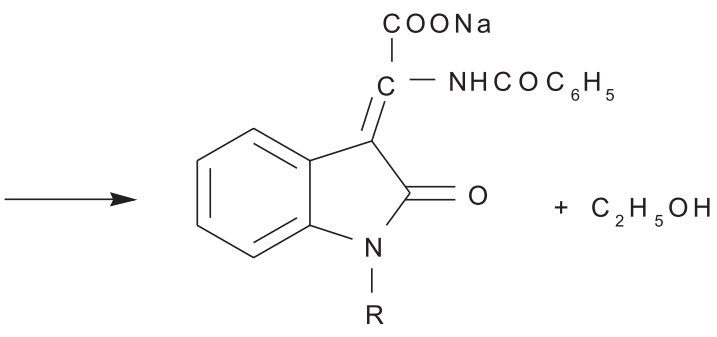

The rate constants $k$ of the alkaline hydrolysis reaction for ethyl esters of 2-(benzoylamino)(1-R-2-oxoindoline-3-ylidene) acetic acid

\begin{tabular}{|l|c|c|c|c|c|}
\hline \multirow{2}{*}{\multicolumn{1}{|c|}{$\mathrm{R}$}} & \multicolumn{5}{|c|}{$\mathrm{k} \cdot 10^{3}, \mathrm{dm}^{3} \cdot \mathrm{Mol}^{-1} \cdot \mathrm{s}^{-1} \mathrm{at} \mathrm{T}, \mathrm{K}$} \\
\cline { 2 - 6 } & $318 \mathrm{~K}$ & $328 \mathrm{~K}$ & $338 \mathrm{~K}$ & $348 \mathrm{~K}$ & $358 \mathrm{~K}$ \\
\hline $\mathrm{H}$ & $1.54 \pm 0.05$ & $2.49 \pm 0.06$ & $3.93 \pm 0.06$ & $6.05 \pm 0.08$ & $12.27 \pm 0.09$ \\
\hline $\mathrm{CH}_{3}$ & $1.11 \pm 0.04$ & $1.83 \pm 0.05$ & $2.94 \pm 0.05$ & $4.58 \pm 0.07$ & $9.51 \pm 0.07$ \\
\hline $\mathrm{C}_{2} \mathrm{H}_{5}$ & $1.12 \pm 0.05$ & $1.89 \pm 0.05$ & $3.02 \pm 0.06$ & $4.74 \pm 0.06$ & $9.73 \pm 0.08$ \\
\hline $\mathrm{n}-\mathrm{C}_{3} \mathrm{H}_{7}$ & $1.21 \pm 0.03$ & $1.99 \pm 0.06$ & $3.14 \pm 0.07$ & $4.93 \pm 0.08$ & $10.19 \pm 0.08$ \\
\hline $\mathrm{n}-\mathrm{C}_{4} \mathrm{H}_{9}$ & $1.23 \pm 0.04$ & $2.02 \pm 0.08$ & $3.21 \pm 0.08$ & $5.01 \pm 0.07$ & $10.28 \pm 0.09$ \\
\hline $\mathrm{C}_{6} \mathrm{H}_{5}$ & $1.55 \pm 0.04$ & $2.49 \pm 0.06$ & $3.95 \pm 0.05$ & $6.08 \pm 0.08$ & $12.45 \pm 0.09$ \\
\hline
\end{tabular}

The rate constants were calculated by the changes in the concentrations of sodium hydroxide in time. The ratio of the concentrations of nucleophile $\left(\mathrm{OH}^{-}\right)$and the ester (substrate) was changed; however, the values of the rate constant did not change within the error of the experiment, i.e. the reaction is described by the kinetic equation of the second order.

The reaction rate constants of alkaline hydrolysis depend on the structure and the length of the hydrocarbon chain at the heterocyclic nitrogen atom (Tab. 1). Introduction of hydrocarbon radicals to the structure of the heterocycle slows down the reaction, while the chain extension accelerates it. The appearance of the phenyl radical in the ester molecule does not practically change the reaction rate, i.e. donor substituents decrease the reaction rate by stabilizing the anion. This indicates an increase of the electron density at the reaction center in transition from the initial state to the activated complex and suggests that alkaline hydrolysis of ethyl esters proceeds by the $\mathrm{B}_{\mathrm{AC}} 2$ mechanism that is known from the literature (Scheme 2) [3].

The effect of the electronic nature of the substituents on the reactivity of ethyl esters was quantitatively assessed by Hammett equation (Tab. 2). The data obtained suggest that the values of the reaction parameter $\rho$ are positive in the temperature range studied; it is additional-<smiles>[R]N1C(=O)/C(=C(\NC(=O)O)C(=O)OCC)c2ccccc21</smiles><smiles>[R]N1C(=O)/C(=C(/NC(=O)OC)C(O)(O)OCC)c2ccccc21</smiles>

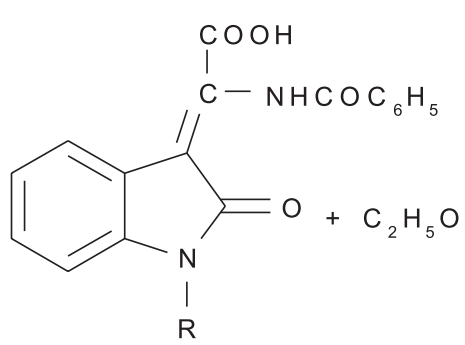
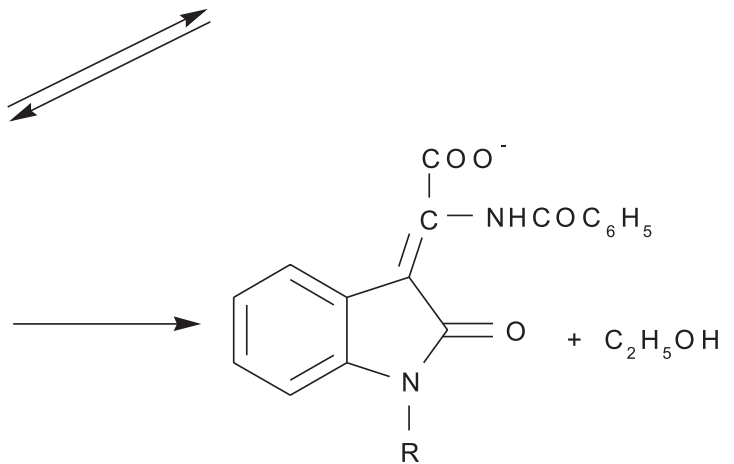
The parameters of Hammett equation $\left(\lg k=\lg k^{0}+\rho \cdot \sigma\right)$ of the alkaline hydrolysis reaction for ethyl esters of 2-(benzoylamino)

(1-R-2-oxoindoline-3-ylidene) acetic acid at different temperatures

\begin{tabular}{|c|c|c|c|c|c|}
\hline $\mathrm{T}, \mathrm{K}$ & $\operatorname{lgk}^{0}$ & $\rho$ & $\mathrm{n}$ & $\mathrm{S}$ & $\mathrm{r}$ \\
\hline 318 & $-2.814 \pm 0.001$ & $0.835 \pm 0.011$ & 6 & $3.87 \cdot 10^{-3}$ & 0.9992 \\
\hline 328 & $-2.604 \pm 0.005$ & $0.784 \pm 0.005$ & 6 & $1.57 \cdot 10^{-3}$ & 0.9998 \\
\hline 338 & $-2.407 \pm 0.001$ & $0.743 \pm 0.010$ & 6 & $3.61 \cdot 10^{-3}$ & 0.9991 \\
\hline 348 & $-2.219 \pm 0.001$ & $0.700 \pm 0.006$ & 6 & $2.03 \cdot 10^{-3}$ & 0.9997 \\
\hline 358 & $-1.911 \pm 0.001$ & $0.665 \pm 0.009$ & 6 & $3.34 \cdot 10^{-3}$ & 0.9991 \\
\hline
\end{tabular}

ly confirmed by the $\mathrm{B}_{\mathrm{AC}} 2$ mechanism of this reaction. The values of the reaction parameter $\rho$ are insignificant. It indicates a low sensitivity of the reaction centre of the substrate to the effect of the substituents, and it can be explained by their remoteness. The value $\rho$ decreases with the temperature increase, i.e. the sensitivity of the reaction centre to the effect of the substituents decreases.

The temperature dependence of the reaction rate constant obeys the Arrhenius equation:

$$
\ln k=\ln A-\frac{E_{A}}{R T} \text {. }
$$

The values of activation energy $\left(\mathrm{E}_{\mathrm{A}}\right)$ and the logarithm of the pre-exponential factor $(\ln \mathrm{A})$ calculated by equation (3) are given in Tab. 3. These data suggest that the elongation of the methylene chain at the heterocyclic nitrogen atom has an insignificant effect on the value of the energy barrier, while substitution of hydrogen to the hydrocarbon radicals
The kinetic parameters of activation $\left(\mathrm{E}_{\mathrm{A}}, \ln \mathrm{A}\right)$ of the alkaline hydrolysis reaction for ethyl esters of 2-(benzoylamino)(1-R-2-oxoindoline-3-ylidene) acetic acid

\begin{tabular}{|l|c|c|c|c|c|}
\hline \multicolumn{1}{|c|}{$\mathrm{R}$} & $\ln \mathrm{A}$ & $\mathrm{E}_{\mathrm{A}^{\prime}} \mathrm{kJ} / \mathrm{mol}$ & $\mathrm{n}$ & $\mathrm{S}$ & $\mathrm{r}$ \\
\hline $\mathrm{H}$ & $7.86 \pm 0.02$ & $55.0 \pm 0.1$ & 5 & 0.045 & 0.9873 \\
\hline $\mathrm{CH}_{3}$ & $3.48 \pm 0.01$ & $49.2 \pm 0.1$ & 5 & 0.020 & 0.9856 \\
\hline $\mathrm{C}_{2} \mathrm{H}_{5}$ & $3.63 \pm 0.01$ & $49.0 \pm 0.1$ & 5 & 0.019 & 0.9861 \\
\hline $\mathrm{n}-\mathrm{C}_{3} \mathrm{H}_{7}$ & $3.54 \pm 0.01$ & $48.7 \pm 0.1$ & 5 & 0.020 & 0.9844 \\
\hline $\mathrm{n}-\mathrm{C}_{4} \mathrm{H}_{9}$ & $3.38 \pm 0.01$ & $48.7 \pm 0.1$ & 5 & 0.019 & 0.9857 \\
\hline $\mathrm{C}_{6} \mathrm{H}_{5}$ & $3.50 \pm 0.01$ & $47.6 \pm 0.1$ & 5 & 0.020 & 0.9840 \\
\hline
\end{tabular}

causes a natural decrease $E_{A}$. The correlation of $E_{A}$ and $\ln A$ with Hammet $\sigma$-constants is statistically insignificant.

According to Eyring equation [6] enthalpy $\left(\Delta \mathrm{H}^{*}\right)$ and entropy $\left(\Delta \mathrm{S}^{\mp}\right)$ of activation were calculated:

$$
\ln \frac{k}{T} \cdot \frac{h}{\mathrm{k}}=\frac{\Delta S^{\neq}}{R}-\frac{1}{R T} \Delta H^{\neq},
$$

where: $h$ - is the Planck constant; $\mathrm{k}$ - is the Boltzmann constant; $R$ - is the universal gas constant; $T$ - is the absolute temperature.

The free energy of activation $\left(\Delta G^{\neq}\right)$was calculated by the second principle of thermodynamics. The data obtained are given in Tab. 4.

The entropy of activation for all compounds is negative, and it is additionally confirmed by the $\mathrm{B}_{\mathrm{AC}} 2$ reaction mechanism. High absolute $\Delta \mathrm{S}^{\ddagger}$ values suggest a highly symmetrical structure of the intermediate formed. The $\Delta \mathrm{H}^{\ddagger}$ values are low, indicating the synchronicity of this reac-

Table 4

The thermodynamic parameters of activation $\left(\Delta \mathrm{H}^{\neq}, \Delta \mathrm{S}^{\neq}, \Delta \mathrm{G}^{\neq}\right)$of the alkaline hydrolysis reaction

\begin{tabular}{|c|c|c|c|c|c|c|c|c|c|c|c|c|c|c|}
\hline \multirow{2}{*}{$\mathrm{R}$} & \multicolumn{5}{|c|}{$\Delta G^{\neq}, \mathrm{kJ} / \mathrm{mol}$} & \multirow{2}{*}{$\Delta \mathrm{H}^{\neq}, \mathrm{kJ} / \mathrm{mol}$} & \multirow{2}{*}{$\Delta \mathrm{S}^{ \pm}, \mathrm{J} / \mathrm{mol}$} & & \multirow{2}{*}{$S$} & \multicolumn{5}{|c|}{$\mathrm{T} \Delta \mathrm{S}^{\neq}, \mathrm{kJ} / \mathrm{mol}$} \\
\hline & $8 \mathrm{~K}$ & $328 \mathrm{~K}$ & $338 \mathrm{~K}$ & $348 \mathrm{~K}$ & $358 \mathrm{~K}$ & & & & & $318 \mathrm{~K}$ & $328 \mathrm{~K}$ & $338 \mathrm{~K}$ & $348 \mathrm{~K}$ & $358 \mathrm{~K}$ \\
\hline $\mathrm{H}$ & 51 & 96.9 & \begin{tabular}{|l|}
98.5 \\
\end{tabular} & 0.1 & 1017 & & \pm 9.9 & 0.9834 & 0.194 & -50.6 & \begin{tabular}{|l|} 
\\
\end{tabular} & -53.7 & \begin{tabular}{|l|}
-55.3 \\
\end{tabular} & \\
\hline$\sigma^{2}$ & & 97 & 95 & & & & & & & -55.2 & & & & -62.2 \\
\hline & & & & & & & & & & & & & & -5 \\
\hline & & 97 & 99 & & & & & & & \begin{tabular}{|l|}
-49.7 \\
\end{tabular} & & & & -5 \\
\hline & & 97 & 99. & .6 & 102 & & & & 1 & \begin{tabular}{|l|}
-49.7 \\
\end{tabular} & -51.3 & -5 & -54.4 & -56 \\
\hline${ }_{6} \mathrm{H}_{5}$ & 93.3 & 96.9 & 98.4 & 100.0 & 101.6 & $5.1 \pm 3.3$ & $-157.8 \pm 9.7$ & 0.9846 & 0.188 & -50.2 & -51.8 & -53.3 & \begin{tabular}{|l|}
-54.9 \\
\end{tabular} & -56.5 \\
\hline
\end{tabular}
for ethyl esters of 2-(benzoylamino)(1-R-2-oxoindoline-3-ylidene) acetic acid

Table 5

The correlation parameters of the equation $y=a+b x$ of dependence of kinetic and activation parameters of the alkaline hydrolysis reaction for ethyl esters of 2-(benzoylamino)(1-R-2-oxoindoline-3-ylidene) acetic acid

\begin{tabular}{|l|c|c|c|c|c|c|}
\hline \multicolumn{1}{|c|}{$\mathrm{x}$} & $\mathrm{y}$ & $\mathrm{a}$ & $\mathrm{b}$ & $\mathrm{r}$ & $\mathrm{S}$ & $\beta, \mathrm{K}$ \\
\hline $\lg k_{318}$ & $\Delta \mathrm{H}^{\mp}$ & $(9.56 \pm 0.03) \cdot 10^{3}$ & $-(12.6 \pm 1.2) \cdot 10^{3}$ & 0.974 & 111 & 616 \\
\hline $\lg k_{328}$ & $\Delta \mathrm{H}^{\mp}$ & $(9.83 \pm 0.03) \cdot 10^{3}$ & $-(13.5 \pm 1.2) \cdot 10^{3}$ & 0.947 & 115 & 621 \\
\hline $\lg k_{338}$ & $\Delta \mathrm{H}^{\mp}$ & $(10.83 \pm 0.03) \cdot 10^{3}$ & $-(14.1 \pm 1.3) \cdot 10^{3}$ & 0.975 & 116 & 621 \\
\hline $\lg k_{348}$ & $\Delta \mathrm{H}^{\mp}$ & $(11.31 \pm 0.02) \cdot 10^{3}$ & $-(15.2 \pm 1.3) \cdot 10^{3}$ & 0.999 & 101 & 618 \\
\hline $\lg k_{358}$ & $\Delta \mathrm{H}^{\neq}$ & $(11.85 \pm 0.03) \cdot 10^{3}$ & $-(15.7 \pm 1.2) \cdot 10^{3}$ & 0.976 & 110 & 633 \\
\hline $1 / \mathrm{T}$ & $\rho$ & $-0.67 \pm 0.02$ & $580 \pm 8$ & 0.999 & $1.8 \cdot 10^{-2}$ & 580 \\
\hline
\end{tabular}


tion series. The correlation equations of $\Delta \mathrm{H}^{\neq}-\mathrm{f}(\sigma)$ and $\Delta \mathrm{S}^{\ddagger}-\mathrm{f}(\sigma)$ relationship where $\sigma-$ are Hammett constants are statistically significant. It is interesting to note that enthalpy and entropy contributions to $\Delta \mathrm{S}^{\neq}$- are similar.

To check the existence of the isokinetic ratio in the reaction series under research the correlations of $\Delta \mathrm{H}^{\neq}$$\operatorname{lgk}_{\mathrm{T}}, \rho-1 / \mathrm{T}$ were studied (Tab. 5). The data in Tab. 5 indicate that they are statistically significant. This allowed us to calculate the isokinetic temperature $(\beta)$ of the reaction by two independent methods. The values $\beta$ obtained are rather close and are above the temperature range studied; it indicates the enthalpy type of control for the reaction of alkaline hydrolysis.

\section{CONCLUSIONS}

The reaction kinetics of alkaline hydrolysis of biologically active ethyl esters of 2-(benzoylamino)(1-R2-oxoindoline-3-ylidene) acetic acids has been studied in a wide temperature range; its $\mathrm{B}_{\mathrm{AC}} 2$ mechanism has been proven with formation of highly symmetrical intermediate. The effect of the substituents at the heterocyclic nitrogen atom on the numerous kinetic and activation parameters of the reaction has been analyzed; isokineticity and synchronicity of the reaction have been proven using independent tests.

Conflict of Interests: authors have no conflict of interests to declare.

\section{REFERENCES}

1. Screening of derivatives of 2-(benzoylamino)(1-R-2-oxoindolin-3-ylidene)acetic acid under the conditions of acute hypobaric hypoxia / I. I. Zamorskii, Yu. S. Bukataru, E. L. Lenga et al. // Вісник фармації. - 2016. - № 1 (85). - С. 67-70. doi: 10.24959/nphj.16.2104

2. Синтез, свойства и биологическая активность амидированных производных 2-(бензоиламино)(2-оксоиндолин-3-илиден)уксусной кислоты / С. В. Колесник, А. А. Алтухов, Э. Ю. Ахмедов, Э. Л. Торяник // Азербайджанский фармацевтический и фармакотерапевтический журн. - 2014. - № 1. - С. 14-18.

3. Reactivity of Derivatives of Phenilanthranilic Acid. I. Reaction kinetics of Alkaline Hydrolysis of 4'-Derivatives of $\beta$-Dimethylaminoethyl Esters of 4-Chloro-N-phenylanthranilic acids in Binary Dioxane-Water Solvent / A. N. Gaidukevich, E. N. Svechnikova, G. P. Kazakov, T. A. Kostina // Organic Reactivity. - 1986. - Vol. 4, Issue 84. - P. 440-449.

4. Аналітична хімія / В. В. Болотов, О. М. Свєчнікова, С. В. Колісник та ін. - Х. : НФаУ, Оригінал, 2004. - С. $427-433$.

5. Altukhov, O. O. Synthesis and properties of 2-(benzoylamino)(1-R-2-oxo-1,2-dyhydro-3H-indole-3-ylidene) acetic acids ethyl esters / O. O. Altukhov // Вісник фармації. - 2013. - № 4. - С. 11-14.

6. Фізична та колоїдна хімія / О. А. Стрельцов, Д. О. Мельничук, В. В. Снітинський, Є. В. Федькевич та ін. - Л. : Ліга-Прес, 2002. - C. 92-94.

\section{REFERENCES}

1. Zamorskii, I. I., Bukataru, Y. S., Lenga, E. L., Kolisnyk, S. V., Altukhov, O. O. (2016). Screening of derivatives of 2-(benzoylamino)(1R-2-oxoindolin-3-ylidene)acetic acid under the conditions of acute hypobaric hypoxia. Visnik Farmaciï, 1 (85), 67-70. doi: 10.24959/ nphj.16.2104

2. Kolesnik, S. V., Altukhov, A. A., Akhmedov, E. Yu., Torianik, E. L. (2014). Azerbaidzhanskii farmatcevticheskii ifarmakoterapevticheskii zhurnal, 1, 14-18.

3. Gaidukevich, A. N., Svechnikova, E. N., Kazakov, G. P., Kostina, T. A. (1986). Reactivity of Derivatives of Phenilanthranilic Acid. I. Reaction kinetics of Alkaline Hydrolysis of 4'-Derivatives of $\beta$-Dimethylaminoethyl Esters of 4-Chloro-N-phenylanthranilic acids in Binary Dioxane-Water Solvent. Organic Reactivity, 4 (84), 440-449.

4. Bolotov, V. V., Sviechnikova, O. M., Kolisnyk, S. V. et al. (2004). Analitychna khimiia. Kharkiv: NUPh, Oryhinal, 427-433.

5. Altukhov, O. O. (2013). Synthesis and properties of 2-(benzoylamino)(1-R-2-oxo-1,2-dyhydro-3H-indole-3-ylidene) acetic acids ethyl esters. Visnik Farmaciï, 4, 11-14.

6. Streltsov, O. A., Melnychuk, D. O., Snitynskyi, V. V., Fedkevych, Ye. V. et al. (2002). Fizychna ta koloidna khimiia. Lviv: Liha-Pres, $92-94$.

\section{Information about authors:}

Kolisnyk S. V., Doctor of Pharmacy (Dr. habil.), professor of the Analytical Chemistry Department, National University of Pharmacy.

E-mail: s_kolesnik@nuph.edu.ua. ORCID: http://orcid.org/0000-0002-4920-6064

Svechnikova O. M., Doctor of Chemistry (Dr. habil.), professor, head of the Chemistry Department, Kharkiv National Pedagogical University named after G. S. Skovoroda

Vinnyk O. F., Candidate of Chemistry (PhD), teaching assistant of the Department of Chemistry, Kharkiv National Pedagogical University named after G. S. Skovoroda

Kolisnyk O. V., Candidate of of Pharmacy (PhD), associate professor of the Pharmaceutical Chemistry Department, National University of Pharmacy

Altukhov O. O., Candidate of Pharmacy (PhD), associate professor of the Analytical Chemistry Department, National University of Pharmacy

Відомості про авторів:

Колісник С. В., д-р фарм. наук, професор кафедри аналітичної хімії, Національний фармацевтичний університет. E-mail: s kolesnik@nuph.edu.ua. ORCID: http://orcid.org/0000-0002-4920-6064

Свєчнікова О. М., д-р хім. наук, професор, завідувач кафедри хімії, Харківський національний педагогічний університет імені Г. С. Сковороди Винник О. Ф., канд. хім. наук, старший викладач кафедри хімії, Харківський національний педагогічний університет імені Г. С. Сковороди

Колісник О. В., канд. фарм. наук, доцент кафедри фармацевтичної хімії, Національний фармацевтичний університет

Алтухов О. О., канд. фарм. наук, доцент кафедри аналітичної хімії, Національний фармацевтичний університет

Сведения об авторах:

Колесник С. В., д-р фарм. наук, профессор кафедры аналитической химии, Национальный фармацевтический университет.

E-mail: s_kolesnik@nuph.edu.ua. ORCID: http://orcid.org/0000-0002-4920-6064

Свечникова Е. Н., д-р хим. наук, профессор, заведующая кафедрой химии, Харьковский национальный педагогический университет имени Г. С. Сковороды Винник А. Ф., канд. хим. наук, старший преподаватель кафедры химии, Харьковский национальный педагогический университет имени Г. С. Сковороды Колесник Е .В., канд. фарм. наук, доцент кафедры фармацевтической химии, Национальный фармацевтический университет

Алтухов А. А., канд. фарм. наук, доцент кафедры аналитической химии, Национальный фармацевтический университет 